\title{
HONOURING ANCESTORS: THE DYNAMIC OF DEIFICATION
}

\author{
Olivier Hekster
}

Funeral, n.: A pageant whereby we attest our respect for the dead by enriching the undertaker, and strengthen our grief by an expenditure that deepens our groans and doubles our tears. ${ }^{1}$

Societies have their own ways of dealing with death. Rituals are always of utmost importance. Philippe ARIÈs, in a magisterial analysis of the development of coping with death in more than a millennium of European history, saw how the "ritualization of death is a special aspect of the total strategy of man against nature". Clearly, death rituals are there for the individual to come to terms with the inevitable demise of someone close. Yet within this ritualisation for the purpose of the individual, community contexts are often crucial. The reaction of any individual to death is shaped by society, and takes place within a social group which can be composed of family, friends, or even paid professionals. ${ }^{3}$ Funerals, therefore, are framed by societal notions. More often than not, they reflect social status and hierarchy. ${ }^{4}$

The expenditures of funerals can be easily joked about - as attested by the quote from Ambrose BIERCE with which this paper opens - but these, too, have a clear function in placing death rituals in a community context. By an elaborate ritual, both the deceased and the survivors are raised above the mundane. Highbrow funerals show the grandeur of those who recently passed away, but may also

${ }^{1}$ A. Bierce, The Devil's Dictionary (London 1911). Some of the themes which are explored in this contribution are looked at, from a variant point of view, in J. de Jong - O. Hekster, 'Damnation, deification, commemoration', in: S. Bénoist - A. Daguet Gagey (eds.), Un discours en images de la condamnation de mémoire (Metz 2008), 79-96.

${ }^{2}$ P. Ariès, The Hour of Our Death (Oxford 1991, 2nd ed.), 604

3 D.A. Davies, Death, Ritual and Belief The Rhetoric of Funerary Rites (London - New York 2002, 2nd ed.), 18.

${ }^{4}$ See for some examples: M. Bloch, 'Tombs and states', in: S.C. Humphreys H. King (eds.), Mortality and Immortality. The Anthropology and Archaeology of Death (London 1981), 137-147. 
indicate the status of those who were closely connected to them. Funerals of, for instance, a beloved member of a royal house, are on the one hand farewell gifts of society to the deceased, but can, on the other hand, also set the surviving royalty apart by the extravagance of the ceremony. Thus, the funeral of Elizabeth the Queen Mother paid homage to a much-loved woman, but also strengthened the problematic position of the house of Windsor. Death is also, in a very obvious way, a moment of transition. As has often been stated, Arnold VAN GENNEP's concept of the tripartite 'Rites of Passage' is of importance. ${ }^{5}$ Its usefulness in analysing death rituals is apparent. Through separation, transition and reincorporation, a person's status changes. This is, of course, common knowledge. Yet it is worth starting this article with these commonplaces, since they are to be kept in mind when looking at Roman imperial funerals.

Roman emperorship was dominantly dynastic. Augustus may have tried to pretend - at least to some parts of society - that there was no official emperorship. It could, therefore, not be inherited, which would in any case have been impossible under Roman law, which did not allow for offices or magistracies to be inherited. Yet, Augustus' continuous attempts to ensure succession by marrying adopted sons to his daughter and raising the profile of his grandchildren must have made reality obvious to all who wanted to see it. At least from the moment that Caligula was given in block all the titles and offices that Augustus and Tiberius had held before him, simply because he was a Julio-Claudian, emperorship was there, and it was there for dynastic taking - a message that Claudius' accession would hammer home emphatically. ${ }^{6}$

${ }^{5}$ A. van Gennep, Les rites de passage (Paris 1909); S.C. Humpreys, 'Dcath and time', in: Humphreys - King 1981, op.cit. (n. 4), 261-283, especially 268-274 and 263. Cf. also the seminal paper by R. Hertz, 'Contribution à une étude sur la représentation collective de la mort', L'Année Sociologique 10 (1907), 48-137, with the comments by D. Coppet, 'The life-giving death', in: Humphreys - King 1981, 175-204.

${ }^{6}$ The importance of dynastic claims is also apparent from the systematic slaughter of imperial relatives by reigning rulers, who clearly deemed them a danger: M. Corbier, 'La maison des Césars', in: P. Bonte (ed.), Epouser au plus proche. Inceste, prohibitions et stratégies matrimoniales autour de la Méditerranée (Paris 1994), 243-291, 274-275, with references. Cf. also Nymphidius Sabinus, who started to spread rumours that he was Gaius' illegitimate son when he began "to think of himself as potentially more than a kingmaker"; T. Wiedemann, 'From Nero to Vespasian', in: The Cambridge Ancient History 10 (1996, 2nd ed.), 261-262. 
Dynastic succession, however, means that the death of a ruler does not just change the status of the person who is dying, but also that of his successor. The latter, through the death of his predecessor, changes from heir-apparent to ruler. Julio-Claudian emperors, at least, could only properly legitimise their position by referring back to Augustus, and to the lineage that traced them to him. It is surely no coincidence that almost every emperor up to and including Nerva was buried in Augustus' mausoleum. The construction of that very building for himself and his family, it could be argued, again shows the first emperor's attempt to create a dynasty, though the meaning of the building must have changed from its inception to the moment it finally became Augustus' funerary monument.

Through the old emperor's death, the new emperor became emperor. It is hardly surprising that the old emperor's death needed proper demarcation. As so often there were constraints. Republican Rome had a long tradition of funerary rites and commemoration of the dead. At funerals, members of family were to give a speech, praising the deceased for his deeds and virtues. These virtues bestowed honour to the dead and his family, and also served as examples of proper behaviour. This laudatio funebris and the funeral as a whole also had symbolic and political implications. ${ }^{8}$ Occasionally, those who had achieved great glory could be awarded a funeral at public expense. This would set them out a truly exceptional, and thus raise their status. At various occasions, the funerary masks of the deceased family members were carried around in procession, making the audience reflect favourably on those clans whose members had done great deeds for Rome. ${ }^{9}$ As is well known, in Republican Rome great lineage was a great asset.

\footnotetext{
${ }^{7}$ M. Macciocca, 'Mausoleum Augusti: le sepolture', in: Lexicon Topographicum Urbis Romae 3 (Rome 1996), 237-239. On the mausoleum, see now: H. von Hesberg, 'Mausoleum Augusti: das Monument', in: ibid., 234-237; P. Rehak, Imperium and Cosmos. Augustus and the Northern Campus Martius (Madison London 2006), 35-53.

${ }^{8}$ W. Kierdorf, Laudatio Funebris: Interpretationen und Untersuchungen zur Entwicklung der römischen Leichenrede (Meisenheim 1980); E. Flaig, Ritualisierte Politik. Zeichen, Gesten und Herrschaft im Alten Rom (Göttingen 2003), 49-68.

${ }^{9}$ G. Wesch-Klein, Funus Publicum: Eine Studie zur öffentlichen Beisetzung und Gewährung von Ehrengräbern in Rom und den Westprovinzen (Stuttgart 1993), 618. Cf. H.I. Flower, Ancestor Masks and Aristocratic Power in Roman Culture (Oxford 1996) and L. Deschamps, 'Rites funéraires de la Rome républicaine', in: F. Hinard (ed.), La mort au quotidian dans le monde romain (Paris 1995), 171-180; E.
} 
Any new imperial ritual was to take shape within the confines of this context. At the same time, the extraordinary position of the emperor was to be made evident. As so often in imperial Roman 'traditions', Augustan precedent became the basis. ${ }^{10}$ At the time of Augustus' death, however, there was no norm, and one may easily forget the unease that this lack of clarity at such a liminal period must have caused. ${ }^{11}$ Some of it, perhaps, surfaces in Suetonius' description of the period:

In their desire to give him a splendid funeral and honour his memory the senators so vied with one another that among many other suggestions some proposed that his cortege pass through the triumphal gate, preceded by a statue of Victory which stands in the House, while a funeral song was sung by children of both sexes belonging to the leading families; others, that on the day of the funeral golden rings be laid aside and iron ones worn; and some, that his ashes be collected by the priests of the highest colleges. One man proposed that the name of the month of August be transferred to September, because Augustus was born in the latter, but died in the former; another, that all the period from the day of his birth until his demise be called the Augustan Age, and so entered in the Calendar. But though a limit was set to the honours paid him, his eulogy was delivered twice: before the temple of the Deified Julius by Tiberius, and from the old rostra by Drusus, son of Tiberius (Suetonius, Augustus 100.2-3).

Cassius Dio cites the eulogies, and also describes in detail the event:

D'Ambra, 'Acquiring an ancestor: the importance of funerary statuary among the non-elite orders of Rome', in: J.M. Højte (ed.), Images of Ancestors (Aarhus 2002), 223-246.

${ }^{10}$ The most important literary sources for the funeral are Suetonius, Augustus 100.2-4; Tacitus, Annales 1.8.3-6; Cassius Dio, 56.34-42. The modern literature is immense. See especially W. Kierdorf, 'Funus und consecratio. Zu Terminologie und Ablauf der römischen Kaiserapotheose', Chiron 16 (1986), 43-69, esp. 62-69; I. Gradel, Emperor Worship and Roman Religion (Oxford 2002), 271-295; P. Zanker, Die Apotheose der römischen Kaiser (München 2004), 16-56; P.M. Swan, The Augustan Succession: An Historical Commentary on Cassius Dio's Roman History Books 55-56, $9 B C-A D 14$ (Oxford 2004), 319-345. Cf. also the still valuable comments on the subject by E. Bickerman, 'Consecratio', in: W. den Boer (ed.), Le culte des souverains dans l'empire romain (Geneva 1973), 3-25.

${ }^{11}$ Notwithstanding the detailed instructions which Augustus left behind. It may be true that "los funerales de los Emperadores non se improvisaban" (J. Arce, Funus Imperatoribus. Los funerales de los emperadores romanos [Madrid 1988], 37), but not even Augustus could have planned the whole public response to his death. 
There was a couch made of ivory and gold and adorned with goldembroidered purple coverings. In it his body was hidden, in a coffin down below; but a wax image of him in triumphal garb was visible. This image was borne from the palace by the officials elected for the following year, and another of gold from the senate-house, and still another upon a triumphal chariot. Behind these came the images of his ancestors and of his deceased relatives (except that of Caesar, because he had been numbered among the divine) and those of other Romans who had been prominent in any way, beginning with Romulus himself (Cassius Dio, 56.34.1-2). ${ }^{12}$

The matrix of traditional Roman funerary rites, including the laudatio funebris, was to be retained. Ancestor masks were brought along; mourners were present in a funerary pomp. The body was buried. But Augustus' extended family included all of Rome - his ancestors were traced back in time to the beginning of Rome itself. His virtues were so prominent that a double eulogy stressed it to the Roman populace. His position had been so prominent that - contrary to tradition - the imagines followed the bier, rather than the other way round. ${ }^{13}$ More importantly, his body was not just physical remains, but had become the body politic - visible through images showing the deceased in various guises. Finally, rather than being 'merely' voted a funeral at public expense, Augustus, by public consent, was also posthumously recognised as having divine status, which had already been bestowed upon his adoptive father Caesar (whose image for that reason had not been shown at Augustus' funeral; a point that must have been emphasised by the powers-thatbe).

Augustus' deification was, in turn, emphasised in the eulogy of the new emperor, who was the son of Augustus' wife, husband of his daughter, and adopted by the great man himself:

It was for all this, therefore, that you, with good reason, made him your leader and a father of the people; that you honoured him with many marks of esteem and with ever so many consulships, and that you finally made him a god and declared him to be immortal. Hence it is fitting also that we should not mourn for him, but that, while we now at last give his body back to Nature, we should glorify his spirit,

${ }^{12}$ Cf. Swan 2004, op.cit. (n. 10), 320-323.

13 Tacitus, Annales 3.76.2; M. Bettini, Anthropology and Roman Culture. Kinship, Time, Images of the Soul (Baltimore - London 1988), 177-179; Swan 2004, op.cit. (n. 10), 320. Possibly Sulla had his funerary bier similarly followed by the procession: Arce 1988, op.cit. (n. 11), 20-22. 
as that of a god, for ever (Cassius Dio, 56.41.9, cf. Suetonius, Augustus 100.3).

This is one of only two pagan laudationes funebres to survive in full from Roman antiquity. ${ }^{14}$ There is a slight problem with the wording, since technically Augustus was not yet granted his divine status on the moment at which the eulogy was held, and the text may therefore be somewhat anachronistic. ${ }^{15}$ Yet, on the whole, it is clear that embedded in traditional elite funerary ceremonies of Republican Rome, a new ritual was to take shape. Through it, not only the heir apparent rose in position - from subject to ruler - but the former ruler too changed status. For emperors, there was now the possibility of becoming a god. This was again no full breach with precedent. In Roman culture, the dead had always had some sort of elevated, if not fully divine, status. ${ }^{16}$ Also, there was the view of "the realm of the dead as social mirror reflection of this world", expressed for instance in Cicero's famous 'Dream of Scipio'. ${ }^{17}$ Augustus' funeral was simply the superlative variant on funerals of other nobles.

The difference may have been only one of degree, it was important none the less. Especially for the imperial successor. What better demarcation than deification - what better way of raising one's own status than becoming the son of a god? Thus, over time, apotheosis became an important part of the new ritual. The shape of this ritual can best be ascertained by looking at the extensive reports surrounding the funerals of Augustus, Pertinax, and Septimius Severus. The central role within these funerals of the deification of the late emperor is continuously apparent. Noticeably, one can eventually recognise a tripartite division in the period between the emperor's death and his deification. In the first stage, a wax pendant of the emperor's body was displayed on the Palatine from the emperor's death up to the day of his funeral. This body double would

\footnotetext{
${ }^{14}$ The other being Antony's laudatio for Iulius Caesar in Cassius Dio, 44.36-49; cf. Kierdorf 1980, op.cit. (n. 8), 150; Swan 2004, op.cit. (n. 10), 325-339.

${ }^{15}$ Swan 2004, op.cit. (n. 10), 339, who suggests that this is retrojection of the practice in Dio's lifetime to vote apotheosis before the funeral (cf. Herodian, 4.2.113.1). Gradel 2002, op.cit. (n. 10), 292 however, argues that "the ascension was basically decreed in advance, and the Senate's later decree merely recognised that it had in fact taken place as scheduled ...".

${ }^{16}$ Gradel 2002, op.cit. (n. 10), 264, with references in n.5.

${ }^{17}$ Cicero, De re publica 6.9-6.29; Gradel 2002, op.cit. (n. 10), 266, with references in $\mathbf{n} .7$.
} 
then, in the second stage, be taken in procession, with representatives of the whole of the Roman world forming part of the pomp. At the Forum Romanum, the new emperor would hold the eulogy praising his predecessor, after which the procession would continue to the Campus Martius, where there was to be a funerary pyre. The third and final stage would see the wax body placed in the pyre, and set alight. This set in process the actual transformation of the human emperor towards the immortal gods - symbolised by an eagle which flew up from the pyre. Separation, transition and reincorporation formed the rite-of-passage that brought about divine status. ${ }^{18}$ Through this new ritual, the Roman imperial system was confirmed. By being heir to a god, the new dynastic emperor secured divine support and status, a point which he could broadcast throughout the empire through images on coins and his own imperial titulature, and by imperial funerary monuments. ${ }^{19}$ At the same time, the presence at the funeral of representations of the Roman world at large was a sign of communal loyalty, whereas the exact order in which they were allowed to operate confirmed the social and political order. ${ }^{20}$ The long line of divi may also have created a sense of continuity of the imperial office. From priestly calendars, it is clear that sacrifices for the deified emperors were still carried out long after their deaths and after the deaths of those who had had so much to gain in deifying them. ${ }^{21}$ Contemporary political needs may have been influential for the act of deification, but once an emperor had become a god, he was there to stay.

18 Pertinax: Cassius Dio, 75.4-5; Septimius Severus: Herodian, 4.2. See especially S.R.F. Price, 'From noble funerals to divine cult: the consecration of Roman Emperors', in: D. Cannadine - S. Price (eds.), Rituals of Royalty. Power and Ceremonial in Traditional Societies (Cambridge - New York - Melbourne 1987), 56-105; Wesch-Klein 1993, op.cit. (n. 9), 19-38; Zanker 2004, op.cit. (n. 10);. On the topography of the ceremony, the importance of the eagle and of the pyre, see Arce 1988, op.cit. (n. 11), 41-43, 131-140 and 140-155.

19 Cf. P.J.E. Davies, Death and the Emperor. Roman Imperial Funerary Monuments from Augustus to Marcus Aurelius (Cambridge 2000), 173 who argues that these monuments should be seen "less as funerary monuments than as magnificent accession monuments, whose message spoke to the living about the living as well as the dead - and the reborn".

${ }^{20}$ Wesch-Klein 1993, op.cit. (n. 9), 21; Zanker 2004, op.cit. (n. 10), 20-34, 40.

${ }^{21} \mathrm{See}$, for instance, the acta of the Arval Brothers and the Feriale Duranum. Cf. Gradel 2002, op.cit. (n. 10), 18-22 and 340-341 with references. 
Importantly, however, there was development over time. Augustus' deification was not followed by that of Tiberius or Caligula. Claudius was deified, but Nero was not, and was even declared hostis. Apparently, under the Julio-Claudians, there was still some flexibility as to how to deal with a deceased predecessor. This must imply that there was as to yet no fully standardised ritual. ${ }^{22}$ Perhaps members of the Julio-Claudian dynasty could still take distance from their predecessor by emphasizing the direct link to Augustus. If so, this may also explain the importance attached to inhumation in Augustus' Mausoleum. ${ }^{23}$ Julio-Claudians could all trace their lineage to the new founder of Rome, and were therefore less dependent on each other. All the same, when the basis of power was weak, one had better make use of ancestry. Thus, Suetonius states that Claudius:

... adopted as his most sacred and frequent oath 'By Augustus'. He had divine honours voted on his grandmother Livia ... also public offerings to the shades of his parents and in addition annual games in the Circus on his father's birthday and for his mother a carriage to bear her image through the Circus and the surname of Augusta, which she had declined during her lifetime. In memory of his brother, whom he took every opportunity of honouring, he brought out a Greek comedy in the contest at Naples and awarded it the crown in accordance with the decision of the judges. ... even in the case of Gaius, while he annulled all his acts, yet he would not allow the day of his death to be added to the festivals, although it was also the beginning of his own reign (Suetonius, Claudius 11).

The very fact that Claudius had Livia deified whereas Tiberius had refrained from doing so is telling. Especially since he must have done so shortly after his accession, and propagated this action through his coinage. ${ }^{24}$ Recently, it has even been argued that

${ }^{22}$ Cf. H.I. Flower, The Art of Forgetting. Disgrace and Oblivion in Roman Political Culture (Chapel Hill 2006), 280: “... the history of the first century AD is characterized by a rich variety of sanctions and by complex memory battles over the past, battles that aimed to define the authority of the ruling family and various individuals within it, the position of the emperor, and the very nature of the principate itself'.

${ }_{23}^{23}$ Arce 1988, op.cit. (n. 11), 59-72; Macciocca 1996, op.cit. (n. 7).

${ }^{24}$ Livia died in 29, and was given a state funeral and interred in Augustus' Mausoleum but was not deified, since Tiberius prohibited it: Tacitus, Annales, 5.1.1; 5.2.1 and Cassius Dio 58.2.1; Suetonius, Tiberius 51.2. Claudius' accession took place on 24 January $\mathrm{AD} \mathrm{41}$, and a flaminica of Diva Augusta is already attested in 
Claudius allowed Caligula's body to have been placed in Augustus' mausoleum, though this can be no more than speculation. ${ }^{25}$ Still, it is interesting to note how Cassius Dio claims that although Claudius had Gaius' images removed and his name taken out of the usual record, he did not allow the senate to have an official vote taken against his predecessor. ${ }^{26}$

Perhaps this emphasis on ancestry can be connected to Nerva's inhumation in Augustus' Mausoleum. He, after all, attempted to link himself to the Julio-Claudians, particularly to Augustus, in whose memory he coined a series of coin types depicting the first princeps on the obverse, including one with the legend DIVVS AVGVSTVS PATER. He also issued a coin type showing a bust of Agrippina, with the legend AGRIPPINA M. F. GERMANICI CAESARIS. ${ }^{27}$ Ironically, the one Julio-Claudian emperor who was certainly not buried in the Mausoleum was the emperor who stressed his descent from Augustus above almost anyone else, emphasising both his patrilineal and matrilineal lineage. Nero's remains, however, according to Suetonius, were placed in the family tomb of the Domitii, after what is described as a private funeral. Noteworthy in this context is Suetonius' remark that one omen for Nero's death was that: "The doors of the Mausoleum flew open of their own accord, and a voice was heard from within, summoning him by name". ${ }^{28}$ For Suetonius, the link between dynasty and dynastic tomb seems to have been straightforward. Nero was posthumously excluded from the dynasty. Not all problematic Julio-Claudians were. Claudius was mocked in the Apocolocyntosis, but deified all the same - the first emperor after Augustus to obtain that honour. Possibly, this was

AD 42 (CIL 8.19492). Consecration coins show Divus Augustus on the obverse and Diva Augusta on the reverse (RIC I ${ }^{2}$, p. 128, no. 101). Cf. Seneca, Apocolocyntosis 9.5; Cassius Dio, 60.4.2; Kierdorf 1986, op.cit. (n. 8), 59-61.

${ }^{25}$ Flower 2006, op.cit. (n. 22), 150: "It seems likely that his ashes were then placed in the Mausoleum of Augustus, perhaps in an unmarked location". Cf. Suetonius, Caligula 59. Arce 1988, op.cit. (n. 11), 74, however, argues that the emperor's damnatio memoriae would have counted as a formal impediment against burial in the mausoleum.

${ }^{26}$ Cassius Dio, 59.4.5-6.

${ }^{27}$ Arce 1988, op.cit. (n. 11), 83; RIC 2, p. 232 no. 134, p. 233 no. 138.

${ }^{28}$ Suetonius, Nero 46.2. Cf. Cassius Dio, 64.6.5. K.R. Bradley, Suetonius' Life of Nero: An Historical Commentary (Brussels 1978), ad loc. suggests that Nero had a funus publicum. Cf. Wesch-Klein 1993, op.cit. (n. 9), 22-27; Flower 2006, op.cit. (n. 22), 200. 
inevitable given that it allowed Nero to be Divi filius, and because Britannicus was still alive and heir apparent. Clearly, in JulioClaudian times there was still some middle ground between deification and damnation.

From the Flavian onwards, however, there seems to have been less flexibility in how predecessors were commemorated. Vespasian himself started in abrasive manner: his lex de imperio placed the new emperor as direct successor to Augustus, Tiberius and Claudius. Fewer emperors are mentioned than omitted. ${ }^{29}$ Through the lex de imperio Vespasian is placed in the Augustan line. Indeed, in some of his actions Vespasian seems to have followed Augustan precedent ${ }^{30}$ Remarkably, however, Vespasian issued no coins commemorating DIVVS AVGVSTVS, and, notwithstanding the attention with which he finished the temple to Claudius, that ruler was not commemorated in coinage either. He may even have abolished the cult of the JulioClaudian divae. ${ }^{31}$ Famously, at Vespasian's death, he is said to have issued a joke: "Oh my, I think I'm turning into a god". In retrospect, it seems obvious that this was to happen, but Vespasian was only the third emperor to get his apotheosis. ${ }^{32}$ On the other hand, there had not been - and would not be - precedent for a natural son not to deify a father who had been in power. Still, Vespasian's death was an important moment for the codification of imperial funerary rites, in that it set the norm for the Flavian dynasty. From this moment onwards, those rulers who were not going to be deified would be vilified and depicted at monsters. Whereas before the Flavian dynasty, it seems that deification needed defence, henceforward the absence of apotheosis needed to be explained. In this light it is noticeable that whereas Augustus struck coins to commemorate

${ }^{29}$ On the lex, see still: P. A. Brunt, 'Lex de imperio Vespasiani', Journal of Roman Studies 67 (1977), 95-116.

${ }^{30}$ B. Levick, Vespasian (London - New York 1999), 73

${ }^{31}$ E.J. Bickerman, 'Diva Augusta Marciana', American Journal of Philology 95 (1974), 362-376, esp. 366

${ }^{32}$ Suetonius, Vespasianus 23.4: Vae, inquit, puto deus fio. Cf. Cassius Dio, 67.17.3. Note how in the proemion of Valerius Flaccus'Argonautica, the apotheosis of Vespasian is predicted. The date of publication, however, is hotly disputed, and this, again, may well be rather written with hindsight: Levick 1999, op.cit. (n.30), $230 \mathrm{n} .27$ with references. Vespasian must, however, have anticipated the advantages for the dynasty of his deification, cf. B. Jones - R. Milns, Suetonius: The Flavian Emperors. A Historical Commentary, with Translation and Introduction (London 2002), 87-88. 
Divus Iulius, and Tiberius did the same for Augustus, "Titus and Domitian re-issued, or restored, not only the 'Divus Augustus' series, but also aes of Tiberius, Livia, Agrippina, Nero Drusus and Germanicus". ${ }^{33}$ More than before, the extended imperial family was to be kept in mind.

Unsurprisingly, then, the Flavians took great effort to emphasise their lineage. Titus commemorated Vespasian and Domitilla (his mother) in his coinage. ${ }^{34}$ Domitian issued more different types, adding to the obvious DIVVS VESPASIANVS, DIVVS TITVS and DIVA DOMITILLA also the legends DIVI CAESARIS MATER and DIVI TITI FILIA alongside DIVA IVLIA. It is unclear in what form the funeral and deification took place of the son of Domitian, who was commemorated in coins with the legend DIVVS CAESAR IMP. DOMITIANI F., the reverses of which show a baby boy sitting on a globe, lifting both hands (or alternatively Domitia seated, extending a hand to a child who stands facing her). ${ }^{35}$ Diva Iulia in any case clearly received cult, as is testified by a southern Italian inscription describing a woman who was priestess of Isis, Cybele, and Diva Iulia Pia Augusta. ${ }^{36}$ The deification of Iulia has been ascribed to Domitian's more than brotherly affection to her. In this way, her divine status may be compared to that of Drusilla, to whom Caligula seems to have been similarly close. Drusilla, however, had only been the second person from the imperial household to be consecrated, and Caligula's behaviour surrounding her funeral had been out of bounds. ${ }^{37}$ When Iulia was deified, there seems not to have been the

${ }^{33}$ RIC 2, p. 302.

${ }^{34}$ RIC 2, pp. 123-124, nos. 59-70. Note also how in AD 80 Domitian is explicitly referred to as CAESAR DIVI F. DOMITIANUS COS VII: RIC 2, pp. 121-122, nos. 48-53.

${ }_{35}$ RIC 2, p. 180 , no. 213 ; p. 209 , nos. $440-443$ (with the legend DIVI CAESARIS MATER); cf. J. Desnier, 'DIVVS CAESAR IMP DOMITIANI F.', Revue des Études Anciennes 81 (1979), 54-65.

${ }^{36}$ RIC 2, p. 181, nos. 219-220 (DIVA IVLIA AVGVSTA), pp. 204-205, nos. 400 and 411 (DIVAE IVLIAE AVG. DIVI TITI F.); CIL 9.1153=ILS 6487; cf. S. Mucznic, 'Roman priestesses: the case of Metilia Acte', Assaph 4 (1999), 61-78, esp. 71 .

${ }^{37}$ Suetonius, Caligula 24.2; Seneca, Dialogi 11.17.4-5; Cassius Dio, 59.11.1-4; Inscriptiones Italiae 13.1, p. 191 (III idus Iun. Drusilla excessi[t]); CIL 14.3576= Inscriptiones Italiae 4.1, 76 = ILS 196 ([Di]vae Drusillae sacrum); CIL $13.1194=$ ILS 197 (Minervae et divae Drusillae sacrum in perpetuum); P. Herz, 'Diva Drusilla', Historia 30 (1981), 324-336. Cf. A. Winterling, Caligula. Eine Biographie (Munich 2003), 80-81 for an attempt to place Caligula's actions 
uproar which the apotheosis of Drusilla (or indeed of Poppaea Sabina) had caused. ${ }^{38}$ By Domitian's reign, deifying family members other than mothers and fathers was no longer an innovation, but rather something that could be done as a matter of course. The emphasis on the divinity of the dynasty was paramount. After all, Domitian also built the arch of Titus, which iconographically documents Titus' apotheosis, and constructed the temple of the Flavians, to which he transferred the remains of his father and brother from (probably) Augustus' Mausoleum. ${ }^{39}$

Trajan's reign ended all flexibility. It has often been commented upon that there is a discrepancy between the Trajan who was distanced (for instance by Pliny) from Domitian's 'divine' behaviour, and the ruler who, more than anyone before him, deified members of his family. ${ }^{40}$ Following what now seems to have become tradition, Trajan deified his predecessor Nerva. It could be argued that in Trajan's case the filial duty needed to be all the more emphatic, since everybody knew he was not related to his predecessor by blood. Attempting to compensate this may have been one of the reasons for Trajan to also deify his birthfather, leading to extraordinary aurei commemorating DIVI NERVA ET TRAIANVS PATER. ${ }^{41}$ The fact that Pliny needed to stress Trajan's sincerity in deification suggests that some might have thought otherwise:

Others have done the same, but with different intent. Tiberius deified Augustus, but his purpose was to introduce maiestas; Nero did the same for Claudius in a spirit of mockery; Titus honoured Vespasian and Domitian honoured Titus, but only for the one to be seen the son and the other the brother of a god. You gave your father his place

surrounding Drusilla's death in light of the succession-question. For a similar explanation for the honours obtained by Caligula's sister: S. Wood, 'Diva Drusilla Panthea and the sisters of Caligula', American Journal of Archaeology 99 (1995), 457-482. The golden image which according to Dio was placed in the senate chamber could be compared to the golden statue at Augustus' apotheosis: Cassius Dio, 59.11.2; Swan 2004, op.cit. (n. 10), 321.

${ }^{38}$ Tacitus, Annales 16.6.2; CIL 11.1331 (=ILS 233).

39 F. Coarelli, 'Gens Flavia, Templum', in: Lexicon Topographicum Urbis Romae 2 (Rome 1995), 368-369; J. Arce, 'Arcus Titi (Via Sacra)', in: Lexicon Topographicum Urbis Romae 1 (Rome 1993), 109-111.

${ }^{40}$ J. Bennett, Trajan. Optimus Princeps (London - New York 2001, 2nd. ed.), 208-209. Cf. S. Bénoist, Rome, le prince et la cite (Paris 2005), 149-153.

${ }^{41}$ RIC 2, p. 297 , nos. $726-727$. 
among the stars ... simply because you thought he was a god (Pliny, Panegyricus 11.1-3).

Trajan, in any case, only deified his father long after the latter's death. Around the same time he also deified his sister Marciana, possibly even on the very day of her death on the $29^{\text {th }}$ of August 112 . The consecration was commemorated through coinage. ${ }^{42}$ When Caligula made his sister a goddess, it caused uproar, and the deification may well have been annulled after the emperor's death. Notwithstanding all the excitement surrounding Germanicus' death, it was never an option for him to be deified. Not even Claudius, who, as cited above, 'took every opportunity of honouring' his brother, spoke of deifying him. Yet Marciana was made a goddess apparently as a matter of course.

At the same time, in the famous restoration coins of Trajan, in the imperial section issues were only minted for previous emperors, excluding the likes of Nero Drusus and Germanicus, whom the Flavians had still commemorated. ${ }^{43}$ Trajan also excluded Caligula, Nero, Otho, Vitellius and Domitian. The only non-divi who are present on coins are Tiberius, who is specifically described as DIVI AVGVSTI FLIVS, and Galba - whose presence has been explained by denoting him as a positive exemplum. ${ }^{44} \mathrm{He}$ alone, of all emperors, is given the legend IMPERATOR in this series. This perhaps links him to the Republican section of the 'restored' series, in which the same legend is used for Quintus Metellus Scipio, the pre-deified Julius Caesar and Pompey the Great. One could even make the argument that this section of Trajan's restoration series was aimed at higher echelons of society, since they are issued in gold, whereas the prototypes were denarii, and the Flavians and Nerva struck their restoration coins in bronze, following bronze prototypes. ${ }^{45}$

\footnotetext{
${ }^{42}$ Inscriptiones Italiae 13.1, p. 201, lines 40-43 (= E. M. Smallwood, Documents Illustrating the Principates of Nerva, Trajan and Hadrian [Cambridge 1966], 32, no. 22, lines 40-43); RIC 2, pp. 300-301, nos. 748-750, 758-761; Kierdorf 1986, op.cit. (n. 8), 50. Cf. Bickerman 1974, op.cit. (n. 31), 363-365 arguing against deification on the same day.

${ }^{43}$ RIC 2, pp. 311-313, nos. 815-836; H. Komnick, Die Restitutionsmünzen der frühen Kaiserzeit. Aspekte der Kaiserlegitimation (Berlin 2001), 158-171.

${ }^{44}$ Komnick 2001, op.cit. (n. 43), 177-178.

${ }^{45}$ Cf. B. Woytek, 'Trajan's restoration of the denarius RRC 343/lb', Numismatic Chronicle 164 (2004), 227-233; Komnick 2001, op.cit. (n. 43), 27-138. I am grateful to Fleur Kemmers for her comments on this point.
} 
Be that as it may - the point is that under Trajan the deified emperors seem to have become some sort of set, and deification of family members, possibly following Flavian precedent, seems to have become the norm. This 'institutionalisation' was continued under the so-called adoptive emperors.

For them, dynastic claims were of utmost importance. ${ }^{46}$ Famously, Antoninus had Hadrian deified, though Cassius Dio and the Historia Augusta state that the emperor was hated by all, and that the senate at first refused to honour him. ${ }^{47}$ Antoninus also transferred his adoptive father's ashes from a private burial ground to Hadrian's new-built Mausoleum. This private burial, however, seems to have had practical rather than ideological grounds: the Mausoleum simply was not finished yet at the time of Hadrian's death. ${ }^{48}$ Still, the need for Antoninus to follow in dynastic footsteps was clear. His pietas in this respect seems, furthermore, to have been at least one of the reasons for his famous epithet.

The columns of Antoninus and Marcus Aurelius further stress the importance for second-century emperors to broadcast their divine ancestry; these commemorative monuments, after all, were no tombs. From Hadrian onwards, all $2^{\text {nd }}$ century emperors were buried in Hadrian's Mausoleum - further stressing how they all were members of an extended dynasty. Finally, the dynastic framework behind the adoptive system further increased the prominence of the imperial women, whose family ties were paramount in the succession policy. Hence, the temple to Divus Antoninus and Diva Faustina in the forum, the latter's presence on the pedestal of Antoninus' column and Sabina's presence on the Arco di Portogallo, and the depictions of her apotheosis on coinage. ${ }^{49}$ Hence, also, the instant deification by

${ }^{46}$ R.M. Geer, 'Second thoughts on the imperial succession from Nerva to Commodus', Transactions of the American Philological Association 67 (1936), 4754; O. Hekster, "All in the family. The appointments of emperors designate in the second century AD', in: L. de Blois (ed.), Administration, Prosopography and Appointment Policies in the Roman Empire (Amsterdam 2001), 35-49.

47 Cassius Dio, 69.23; Historia Augusta, Hadrianus 24.5, 25, 27; Historia Augusta, Pius 2.5.

${ }_{48}$ Davies 2000, op.cit. (n. 19), 35. Cf. Flower 2006, op.cit. (n. 22), 235.

${ }^{49}$ A. Cassatella, 'Antoninus, divus et Faustina, diva, aedes, templum', in: Lexicon Topographicum Urbis Romae 1 (Rome 1993), 46-47; S. Maffei, 'Columna Antonini Pii', ibid., 298-300; D. Kleiner, Roman Sculpture (New Haven - London 1992), 254-255, 287; Coins of the Roman Empire in the British Museum 3 (London 1936), 362 no. 955 with pl. 66. 
Hadrian of his mother-in-law Matidia the Elder. Parts of Hadrian's laudatio at her funeral have survived, as have numerous commemorative coins. ${ }^{50}$

Dynastic continuity was continuously emphasised. The best example of this is, of course, the retro-active self-adoption of Septimius Severus in the Antonine dynasty. Commodus, much to Cassius Dio's dismay, was deified, and Septimius' new lineage was a continuous divine ancestry, all the way back to Nerva. A well-known dedicatory inscription from Mauretania Caesariensis (AD 195) is illustrative at this point:

Imp(eratori) Caesari divi M(arci) Antonini/ pii Sarmatici Germanici filio/ divi Commodi fratri/ divi Antonini/ Pii nepoti divi [Hadria]ni pronepoti/ divi [Traiani Parthici ab]nepoti divi/ [Nervae adnepot $] i^{51}$

The Severan emphasis on their domus divina is much discussed. It was emphasised through epigraphic and other attestations, such as the impressive gold dish from Rennes in Gallia Lugdunensis, which is adorned with sixteen aurei, depicting the imperial family in the company of the deified Hadrian, Antoninus Pius, Faustina the Elder, Marcus Aurelius, Faustina the Younger, and Commodus. ${ }^{52}$ However, this emphasis was simply the next step in an ever-more standardised framework, much as Septimius Severus' funeral, described by Herodian, ${ }^{53}$ was the next step in the ritualisation of imperial death.

The main steps in this process had been taken long before Severus took the throne. As the principate continued and emperorship became ever more institutionalised, the overbearing position of the imperial household was there for all to see. Clearly, this had consequences for the way the imperial family was to be commemorated as well.

Much like the emperorship itself, the death rituals of the emperors and those surrounding him took shape in a continuous

${ }^{50}$ CIL 14.3579 (= Smallwood 1966, op.cit. [n. 42], 56 no. 114); RIC 2, p. 300, nos. 751-756.

51 CIL 8.9317; O. Hekster, Commodus. An Emperor at the Crossroads (Amsterdam 2002), 189-191.

${ }^{52}$ G. Lerouz - A Provost, Carte archéologique de la Gaule 35: L'Ille-et-Villaine (Paris 1990), 198-199. Epigraphic attestations: Example giving EDH nos. HD015530 (= $A E$ 1968.518, 1975.853), HD016963 (= $A E$ 1962.304), HD022430 (= $C I L$ 8.25808), HD026967 (= AE 1913.46).

${ }^{53}$ Herodian, 4.2 . 
process of adaptation, in which the period of the adoptive-emperors was of utmost importance.Thus, the funeral of $\mathrm{L}$. Licinius Sura in AD 108 was the last funus publicum to be bestowed upon someone outside of the imperial family. ${ }^{54}$

The imperial family dominated public funerary rituals. What shape the actual burials of the 'minor royals' - like Marciana and Matidia - took, cannot be told. It is possible, but unlikely, that they were tripartite burials, like the funerals of the emperors themselves. In this respect, however, the ritual activities, and hence the dynamics of ritual, are lost to us. One can only guess what the impact of empire may have been.

Arnhem, January 2008

54 PIR L 253; Wesch-Klein 1993, op.cit. (n.9), 31-32. Possibly, C. Iulius Quadratus Bassus (PIR I 508) was granted a state funeral in $\mathrm{AD} 117$, but the evidence is inconclusive. In any case, the funeral took place in Pergamum rather than in Rome itself. Cf. Wesch-Klein 1993, 91-101 for a similar development of the luctus publicus. 